\title{
Development-induced Displacement in Haiti
}

\author{
Philip Howard
}

\begin{abstract}
In recent decades the people of Haiti have faced ecological disaster, political upheaval, and persistent economic hardship. These afflictions have motivated hundreds of thousands of Haitians to migrate to other Caribbean countries, the United States and Canada. While many observers know that mass migration was the result of Haiti's problems, it was the mass migration from rural highlands to urban slums that created the important preconditions for the violent expression of collective grievances. Since the 1950s, certain development projects in the highlands have displaced large numbers of Haitians by causing or exacerbating the severe environmental degradation that destroyed their land, water and fuelwood resources. Specifically discussed are the Péligre Dam and the use of Green-Revolution technology. The result was that squatter settlements at the edge of Port-au-Prince and the district capitals grew crowded, volatile and violent.
\end{abstract}

\section{Précis}

Dans les dernières décennies la population d'Haïti a été confrontée à des désastres écologiques, des bouleversements politiques et un marasme économique persistant. Ces avatars ont amené des centaines de milliers d'haitiens à émigrer vers d'autres pays des Caraibes, vers le Canada ou vers les Etats-Unis. Si de nombreux observateurs sont bien conscients que cette émigration massive a été le principal résultat des problèmes d'Haïti, il y a aussilieu de s'aviser du fait

Philip Howard is Doctoral Candidate, Department of Sociology, Northwestern University, Chicago.

This research was made possible by a grant from the Americas Branch of the Canadian International Development Agency (CIDA). For more information and copies of the final policy paper contact Philip Howard, Department of Sociology, Northwestern University, Chicago. que c'est la massive migration interne depuis les régions montagneuses des campagnes vers les bidonvilles urbains qui est à l'origine des importantes conditions d'engendrement de l'expression de la colère collective. Depuis les années 1950, un certain nombre de projets de développement dans la zone montagneuse ont entraînéle déplacement d'un grand nombre d'haïtiens, en engendrant ou amplifiant la sévère dégradation environnementale menant à la destruction des terres, des points d'eau et des ressources en bois combustible. On discute ici spécifiquement le cas du barrage Péligre impliquant notamment l'utilisation de technologies relevant de la "Révolution Verte". Le résultat patent en a été que les communautés d'occupants illégaux de la périphérie de Port-auPrince et des capitales de districts ont vu nettement augmenter leur nombre, leur instabilité et leur niveau de violence.

\section{Introduction}

Haiti is the most impoverished and environmentally degraded country in the western hemisphere. Although most developing countries experience rapid urbanization in some form, district capitals in Haiti have grown at unusually rapid rates in the past few decades. The capital of Haiti, Port-auPrince, has grown at a faster rate than most of the world's larger megacities, straining local infrastructure and forming the political cauldron from which civil strife has boiled up. Civil strife and economic malaise in Haiti have often resulted in the migration of large numbers to the shores of Florida and the cane fields of the Dominican Republic and other Caribbean countries. However, mass migration from rural to urban areas over several decades created the initial conditions for civil strife: densely populated slums where solidarity between people with common health, economic and political grievances could build.
Haiti's tumultuous history is the background for its current predicament, because at no time since the revolution of 1804 have elites provided education or new sources of income to the large majority of Haitians from whom wealth was extracted (Mintz 1995). This context of endemic poverty is important for understanding recent turmoil, and observers are correct to look into class, corruption, and vodoun culture that are the most apparent facets of Haiti's political culture. However, mob violence in the streets of Port-au-Prince and other major urban centres has disrupted national politics more than protest in rural communities, and it is important to understand how and why these urban slums formed. Even though some analysts have also sought to associate rapid population growth and urban poverty with civil strife in Haiti, they often stop short of tracing popular grievances back to an important source-migration induced by the environmental consequences of development projects.

The urban population of Haiti has grown phenomenally in the last few decades. Natural growth rates in cities are often lower than in rural areas, and the population boom of cities like Portau-Prince, Cap Haitian and Jacmel is largely the result of heavy migration from farming communities in the highlands. Some of this migration is due to general economic malaise and political strife that has long afflicted many highland communities. However, both large industrial development projects and smaller Green Revolution development projects induced a significant portion of the migration into Haiti's urban centres. The economic opportunities created by these projects were temporary, and they were created at the expense of the ecological resources used by the vast majority of the population in subsistence and small-scale agriculture. 
There is no nationwide empirical evidence with which to compare migration numbers from communities targeted for development with migration numbers from communities left to their own devices. However, the anecdotal and empirical evidence from specific development projects in Haiti is strong. Development-induced migration occurred at different rates in Haiti: projects that radically disrupted local ecology sent people to the cities or neighbouring regions at a rapid pace; projects that gradually degraded local ecology induced a slower pace of migration. This paper will review examples of each kind of developmentinduced migration. First, the social and ecological impact of the large Péligre hydroelectric and irrigation system in the Artibonite District will be explored. Second, a series of smaller highland development projects will be studied with the aim of identifying the inappropriate assumptions common to many such projects.

\section{Development in Haiti}

\section{Economic and Political Context of Development in Haiti}

Jean-Claude "Baby Doc" Duvalier inherited his father's title of "President For Life" in 1971 and led the country through several years of economic prosperity. However, the economic growth was unsustainable largely because of the new President's corrupt and lacklustre leadership. His regime violently suppressed political opposition, but after 15 years of economic and social stagnation protests and riots rocked the country's capital, Port-auPrince. On February 7, 1986, JeanClaude Duvalier fled Haiti for France (Abbott 1988).

In the following decade civil disorder constantly erupted on the political landscape of the country, and Haiti undertook a perilous path to democracy. Protests throughout the country frequently expressed dissatisfaction with government leadership, but violence in the capital's slums has been the most pernicious threat to state security. Although these slums remain an important part of Aristide's power base, they remain impoverished, overcrowded, and volatile communities.

Development projects are designed to foster development, but they can have unintended effects on rural communities and ecosystems. Land in Haiti has been stressed by overproduction and erosion in the past, but several development projects in rural Haiti have significantly degraded large parts of the countryside, displacing many families.

The Haitian state has long been run by a small number of powerful families, and this "educated urban and largely mulatto elite used the state to enrich itself by any means possible. Its members paid little or no taxes or customs duties, or even their utility bills" (Maingot 1995, 60). One observer called Jean-Claude Duvalier's regime a "keptocratic state" that sought to nationalize the economy so that corruption in the private sector could interact symbiotically with corruption in the public sector (Maingot 1995, 61). Since large sums were skimmed off public works projects many were illfated from the beginning, and few of the revenues generated from import duties have ever been put to rural development.

Most development projects sponsored by foreign agencies, by contrast, remained under close scrutiny by the donor community and were a relatively minor source of revenue for local elites. Still, projects had to work around the local elites that manipulate policies, programs and property rights in their favour. Rural populations in Haiti are managed by the administrative chefs de section, large land owners, and people who organize local exports, the spekulate.

\section{Population Growth and Urbanization}

Between 1965 and 1995 the total population of Haiti grew from 4.2 million to 7.2 million despite extremely high

\section{Figure 1: Population Growth and Urbanization in Haiti, 1950-2010}

(millions of people)

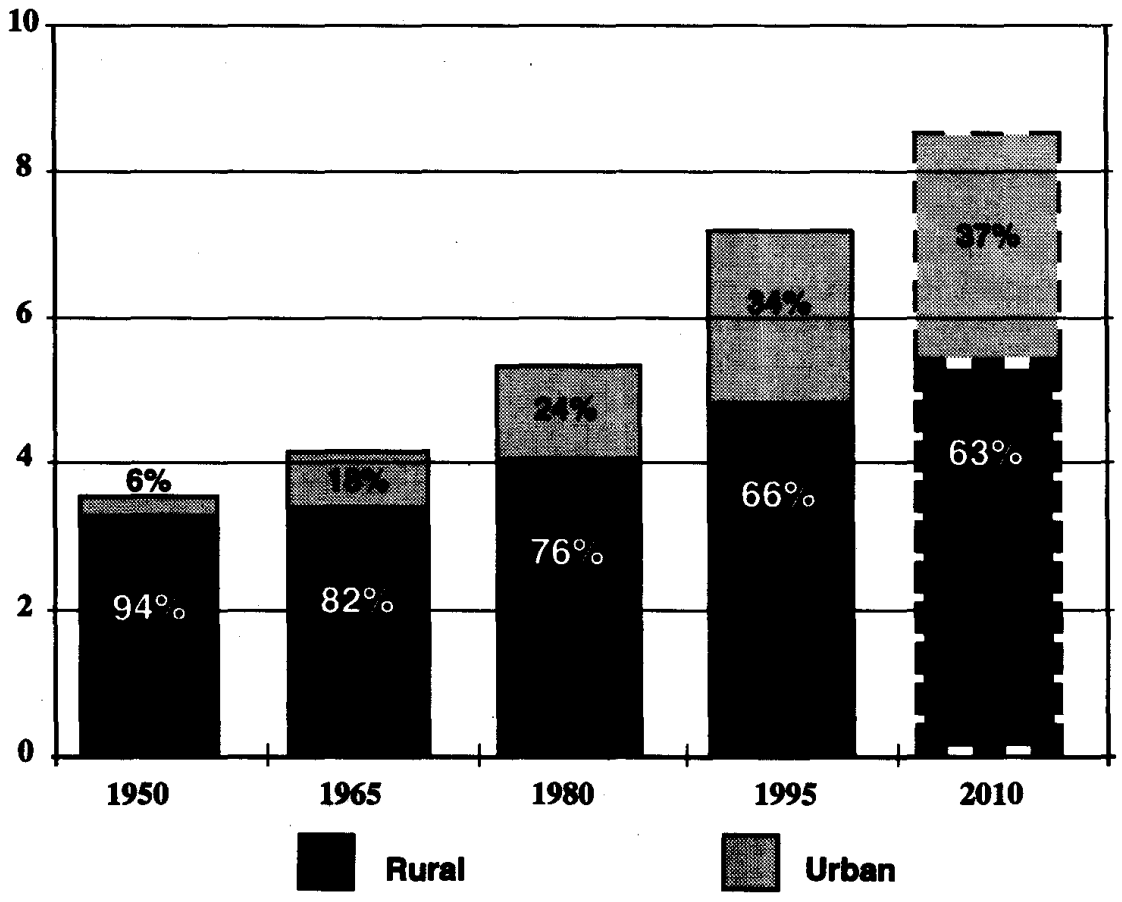

Sources: World Resources Institute, World Resources 1994-95 (Oxford: Oxford University Press, 1994), 286; World Bank, Social and Economic Indicators 'Stars' Data Set. 
rates of infant mortality and extremely low life expectancy. In contrast to the annual growth rate of 1.8 percent for the total population, the urban population grew by about 3.6 percent each year, and today one third of the population lives in burgeoning urban centres. Figure 1 details both rapid growth in the number of people living in Haiti and rapid growth in the proportion of Haitians living in urban areas. The state capital of Port-au-Prince has grown more than tenfold since 1950 , and is now home to at least 2 million people. ${ }^{1}$

Even though the rate of growth in urban populations is high, about two thirds of the total population still live in rural areas. Some experts estimate that it takes one hectare of good land to feed two people for a year. Overall, rapid population growth in Haiti has resulted in the highest population density in the Americas-2.5 people per hectare. However, the quality of the land in many places deteriorated over this period.

Whereas environmental degradation induced people to leave rural areas, the hope of economic prosperity enticed people to come to the cities. In the mid-1970s almost half the urban population had access to piped drinking waters while only 3 percent the rural population had the same privileges. Even after the economic embargo, industry in Port-au-Prince employed less than 6 percent of the population yet accounted for 15 percent of the nation's GDP and garnered most of the state's meagre public expenditure (Bryan 1995, 68).

\section{A Sensitive Ecology}

Haiti is a mountainous Caribbean country of less than 2.8 million hectares. Almost two-thirds of the countryside has a slope of more than 20 percent, and two-fifths of the land is above 400 meters in elevation, making the soil particularly susceptible to erosion by torrential storms that pummel the land from June to October. Experts estimate that only one-third of the land is actually cultivable by conventional standards, though over one-half of the land is now put to some form of agricultural production (White and Jickling 1995, 8). Although the country is semiarid and protected against moist trade winds by the Dominican Republic, its soils are like those of other tropical islands-fertile but thin. Rapid deforestation and intense farming in several regions exposed the soil to the energy of wind and rain, which over a few decades carried away the livelihood of many rural families.

\section{The Artibonite District and The Péligre Dam}

Between the two coastal towns of Gonaives and Saint-Marc is a large plain of rich, fertile soil called the Artibonite District. A system of rivers flow from Lake Péligre in the central highlands of Haiti, nurturing the soils of one of Haiti's most agriculturally productive areas. Several decades ago the Artibonite District also developed the country's most complex irrigation system, a project that temporarily enhanced local agricultural production and eventually displaced large numbers of people.

While the construction of a hydroelectric and irrigation facility increased the production of some crops in the valleys downstream, the valleys upstream were heavily logged and subsequently eroded. Declining agricultural production upstream forced many people to migrate to the lowlands or urban centres. Since competition for land grew fierce in the Artibonite, an increasing number of families either moved into urban slums or chose to resolve disputes with machine guns purchased from the army.

Until 1949 the Artibonite was farmed by small producers and the land was of little agricultural value. That year, however, the government began to plan for a new hydroelectric and irrigation facility, about 100 kilometers upland from the mouth of the Artibonite River. With a US $\$ 40$ million loan from the American government, the Artibonite Valley Development Organization (AVDO) planned a hydroelectric facility to provide power for Port-au-Prince to the southeast and irrigate the Artibonite valley to the northeast. Social elites were the first to hear of the project, and they began to buy up tracts of land for about one US dollar per hectare. Knowing that new areas of land were going to become productive, wealthy elites arranged for property rights to lands that were either unclaimed or occupied by peasants without clear titles.

The government organized a land registry program two years after making the decision to develop the Artibonite Valley. Using aerial photography engineers determined that 32,000 hectares of 45,000 hectares would benefit from the project, and that the average farm size was around 1.2 hectares. However, the average farm size was probably much lowerlittle over 1 hectare per farm. Moreover, the land survey did not track the number of people living off each parcel of land. In Haiti land property is traditionally divided in equal portions between heirs, and by underestimating the population density planners could not anticipate the demand for irrigation. $^{2}$

Under the direction of the AVDO the Dam was completed and Lake Péligre created in 1956. Wherever irrigation facilities expanded in the next few decades, absentee landowners managed much of the agriculture on the newly productive land through rent and repression.

By 1963 much of the loan to the AVDO had been spent and the land registration left incomplete. Moreover, the United States suspended all economic and military assistance to Haiti because of the corruption and repressive regime of "Papa Doc" Duvalier. The rapid modernization of agriculture in the valley had significantly increased the area of rice cultivation and the volume of rice produced without creating the indigenous skills to maintain the irrigation system. Lacking the support of fertilizers and attention of engineers, the infrastructure deteriorated, accelerating the salinization of the soils. The AVDO reopened in 1971, but it was not until five years later that 
a loan from the InterAmerican Development Bank allowed the irrigation system to be rehabilitated.

Haiti's production of rice increased significantly after the construction of the Péligre Dam, largely because of the expanding irrigation of the Artibonite District. By the late 1970s the Artibonite Valley region produced 80 percent of Haiti's rice across 32,000 hectares, and had 2 large state mills and over 200 smaller mills to collect and clean domestic, American and Taiwanese varieties of rice.

At the time; the government estimated that 20 percent of the land was worked by renters, 20 percent was worked by sharecroppers, and 60 percent of the land was worked by owner/ occupants (Perez and Bona 1983, 9-10). However, these figures belie the complex reciprocal relationships that develop between neighbours in Haitian farming communities. Most families own some small plots and alternatively hired labour or served as labour when necessary. Because a minority of landlords owned larger plots of better quality, small producers increasingly hired themselves out to supplement the income from their less productive land. The scarcity of land resources in rural communities rose rapidly: at the outset of the decade 70 percent of the farmers had plots of less than $1.3 \mathrm{hec}-$ tares; by the end of the decade 85 percent of the farmers had plots of less than 1.3 hectares (Durand 1983, 19).

The land registration process in the Artibonite did not begin again until 1978 , fifteen years after it had stalled. Complete reports started coming back in 1981, revealing astounding population growth since the early surveys. Laborers had been brought in by absentee landlords, families from neighbouring regions migrated in search of new opportunities, and high fertility rates in many communities resulted in the constant subdivision of small plots between heirs. One study of 16 communities in 1951 found that property sizes ranged between 0.65 and 1.27 hectares, with the average plot measuring about 0.96 hectares. Thirty years later, property sizes in the same com- munities ranged between 0.22 and 0.56 hectares, with the average plot measuring only 0.45 hectares (Zamor 1983, 30-31).

One significant reason for the rising number of people in the valleys below the Péligre Dam was the utter decimation of agriculture in the central plateau above the dam. The most serious consequence of the Péligre was the logging that followed. Tropical forests in the highlands of Haiti had been inaccessible to logging interests until a network of good roads were built to service the dam. Consequently, the river basins above the dam were rapidly deforested, degrading the rivers and watersheds, and exposing a significant amount of topsoil to erosion. In turn, most of the eroded soil quickly collected at the bottom of the Péligre reservoir.

The dam had a formidable impact on land use patterns in the Artibonite. Table 1 reveals a radical change in land use along the Samana and Thomondes Rivers that feed into the Péligre reservoir. Both are representative of the effects of the Péligre development on upstream rivers. While the reservoir flooded three thousand hectares of land along the shore of the Artibonite, local farmers also cleared land to feed growing communities in the plateau.

Given that the population density of the entire region was estimated at one person per hectare in 1956, about 34,300 people were living in these two basins at the time. Assuming that the birth rate in these two basins was similar to that of other rural areas, the population of these two basins would have been between 42,700 and 49,500 in 1978. Using the conservative measure of the region's population, the changing resource base for communities in the Samana and Thomondes basins can be estimated.

Forests supply fuel, food and building supplies, and in 1956 there were roughly five people for every hectare of forest in the region. Twenty years later there were fifteen people living off every hectare of forest in the region. The addition of more land for agricultural production was offset by the rising number of people and severe erosion. On average there were 3.8 people living off each cultivated hectare in 1956, yet twenty years later there were 4.5 people living off each cultivated hectare. Restricted water flow also created a health hazard for

Table 1: Land Use and Resource Scarcity above the Péligre Dam, 1956 and 1978

\begin{tabular}{|c|c|c|c|c|c|c|c|c|}
\hline \multirow[t]{2}{*}{ Land Use } & \multicolumn{2}{|c|}{$\begin{array}{l}\text { Samana } \\
\text { Sub-Basin } \\
\text { (hectares) }\end{array}$} & \multicolumn{2}{|c|}{$\begin{array}{c}\text { Thomondes } \\
\text { Sub-Basin } \\
\text { (hectares) }\end{array}$} & \multicolumn{2}{|c|}{$\begin{array}{l}\text { Regional } \\
\text { Average } \\
\text { (\% of total) }\end{array}$} & \multicolumn{2}{|c|}{$\begin{array}{c}\text { Population per } \\
\text { Resource Base } \\
\text { (population' } \\
\text { hectare of } \\
\text { resource) }\end{array}$} \\
\hline & 1956 & 1978 & 1956 & 1978 & 1956 & 1978 & 1956 & 1978 \\
\hline Forest Woodland & 4,030 & 700 & 3,200 & 2,140 & 21 & 8 & 4.7 & 15.0 \\
\hline Agriculture & 2,570 & 3,600 & 6,400 & 5,730 & 26 & 27 & 3.8 & 4.5 \\
\hline $\begin{array}{l}\text { Area Denuded, } \\
\text { Eroded or Rocky }\end{array}$ & 5,200 & 7,500 & 12,900 & 14,630 & 53 & 65 & 1.8 & 1.9 \\
\hline Total & \multicolumn{2}{|c|}{11,800} & \multicolumn{2}{|c|}{22,500} & \multicolumn{2}{|c|}{100} & 1.0 & 1.2 \\
\hline
\end{tabular}

Sources: M. Frenette et al., "Cas Historique de Sedimentation du Barrage Péligre, Haiti," Canadian Journal of Civil Engineering, Vol. 9 (1982):210; World Resources Institute, World Resources 1994-95 (Oxford: Oxford University Press, 1994), 286; World Bank, Social and Economic Indicators 'Stars' Dataset. 
communities by turning the water brackish.

Acute shortages of land, fuelwood and fresh water resources began to displace people from the region above the dam in the late 1970 s. Some moved to Port-au-Prince and other urban centres in search of work; some moved downstream in search of work or land to rent; others moved across the border into the Dominican Republic either permanently or in search of seasonal labour (Orenstein 1995). The decade of the 1970s saw a significant change in land distribution in the valley below, due in part to the influx of migrants.

Although the state expanded irrigation facilities in the Artibonite and made the region the leading producer of rice, a majority of properties downstream were suffering from chronic drainage and salinity problems by the mid-1980s. Agriculture was still more productive in the valley than in many places upland, and a large number of displaced people came in search of work or small plots of land to buy, rent or occupy. When possible, the AVDO subsidized fertilizers and repairs to the irrigation system, but dwindling state resources in the late eighties made comprehensive agricultural development difficult.

The Péligre Dam has become a textbook example of the importance of environmental impact assessments to sensible development planning. Original designs for the dam were informed by sedimentation studies done in 1925 , and project engineers estimated that the dam would have an effective life of 180 years at a sedimentation rate of $3.45 \times 106 \mathrm{~m}^{3}$ each year. However, after 23 years the average silting was three times of the design estimates$9.60 \times 106 \mathrm{~m}^{3}$ each year had collected in the reservoir behind the dam. Deforestation and rapid population growth had radically altered the vegetative cover of many slopes, and the erosion altered water courses, expanded river banks, and resulted in gullying, mud slides and increased flocculation in the reservoirs (Frenette 1982). This rapid sedimentation interferes with the flow of water, reduces the holding capacity of the reservoir, and effects the efficiency of the dam.

Today siltation in the reservoir has reduced the holding capacity of the Péligre Dam by about 50 percent, and without dredging, repairs and erosion abatement strategies the full life of the dam will be reduced from the original estimate of 180 years to a mere 80 years. In other words, the dam may be completely silted up in 40 years.

Since the construction of the Péligre hydroelectric and irrigation system, the percentage of Haitians living in urban centres has grown more than fivefold, from 6 percent to 33 percent of the total population. This change was partly the result of development-induced migration from the Artibonite District. The Péligre Dam increased the productivity and value of downstream land in the years following its construction. Anticipating the rise in value, Haitian elites snapped up many properties and leased them back to the many local farmers desperate to feed growing families. As communities below the dam grew, heirs were forced to split diminishing land resources, and the appearance of displaced people from the highlands placed a greater burden on local fuel, land and freshwater resources. This pressure induced another wave of migration, mostly into the squatter settlements at the edge of Port-au-Prince.

The government of Haiti now identifies the Artibonite District as the area most urgently in need of land reform. The Artibonite has the largest number of properties held by absentee landlords in the country, and since land productivity is diminishing, the competition for good land between migrants, renters and small-holders has grown violent. Other highland areas did not see as much investment in agricultural development as the Artibonite, but still contributed large numbers of people to the growing coastal cities.

\section{Agricultural Development \\ Projects in the Highlands}

Three key assumptions structured many of the agricultural development projects sponsored by foreign agencies, and these three assumptions were in part responsible for their long-term failure to generate sustainable agriculture. First, the superiority of GreenRevolution expertise and technology over that of indigenous farmers was assumed. Second, many planners assumed that Haitian farmers were highly independent producers who combated poverty by making only short-term investments in their land. Third, many planners worked around political territories rather than local ecology. Thus, foreign aid to agriculture often meant offering income-related incentives to specific individuals, regardless of their location in the watershed, to try techniques that would not be sustained once the funding stopped.

\section{The Green Revolution and Incentives}

Over two centuries ago Haitian peasants fought and won a revolution for independence from France and freedom from slavery. Over the past half century Haitian peasants lost the fight for a Green Revolution that was to bring them economic prosperity and feed their growing numbers.

The Haitian government tried to develop the country's industry at the expense of its agriculture even though the vast majority of the population were subsistence farmers in rural highlands. Small producers were heavily taxed though the state offered little agricultural or social assistance. Although significant financial support and technical expertise from the developed world came to Haiti over the half century, the Green Revolution was largely unsuccessful. Many large agricultural development projects did not consider the fragility of highland ecology, lowering the overall productivity of farms and driving people off the land.

To encourage the Green Revolution, agencies offered subsidies and credits on the condition that farmers adopt the recommendations of experts on highyield plant species, special tools and land-use techniques. This meant that 
outside experts could effectively dictate the terms of agricultural production for large areas, and even if the expert knowledge contradicted indigenous knowledge about local ecosystems, the farmers had an incentive to participate. In many cases the most labour-intensive techniques involved the construction of dams and bracing walls, and once the payment of wages and food stopped many of these structures fell into disrepair.

By the early 1980 s new assumptions about peasant participation had to be worked into rural development projects. The new approaches recognized that farmer remuneration was not necessary for technique adoption and sometimes even acted against technique maintenance and diffusion; there existed a number of low-input, indigenous, anti-erosion techniques and agroforestry practices that could be improved; and peasants had a natural incentive to conserve soil in order to increase agricultural production (White and Runge 1994, 2).

However, "development" was still an exercise of formalizing and commodifying reciprocal arrangements between farmers. A recent watershed management project in southwest Haiti, discussed below, did not take advantage of the informal labour-reciprocity traditions of many rural Haitian farmers, and effectively strengthened the power of local elites and political bosses-the chefs de section.

\section{Haitian Peasants as "Free Riderș"}

One of the crucial mistakes of many agricultural development strategies has been the assumption that Haitian peasants were "free riders" who chose to abuse common property, benefit from collective action without participating, and invest only for short-term gain. In the early 1960 s the human capital of rural Haiti was studied by two major lending organizations: the OAS concluded that "no farmers' organization in the ordinary sense exists in Haiti" and the USAID concluded that the Haitian peasant was, "except un- der extreme duress, incapable of group action to defend his interests" (OAS 1963; Schaedel 1962, iii). A recent empirical study of collective action on watershed management exposed this myth (White and Runge 1994). Haitian communities do have strong traditions of cooperation, but old traditions of labour reciprocity were quickly eroded by development projects that demanded decisions from individual male heads of households and imposed more formal economic practices over informal traditions.

For example, White and Runge studied the cooperative habits of landholders within a watershed near Maïssade, in the central highlands of Haiti. Conventional wisdom predicted that collective management of the watershed (1) would be of less interest to upstream farmers than downstream farmers; (2) would be of less interest to farmers who rented their land than those who owned their land; and (3) that a farmers' contribution to the effort would only be in proportion to the expected benefits.

However, the study found that there was no difference in the labour contributed by those who benefited and those who did not, and that insecure land tenure did not affect a farmer's decision to cooperate. A farmer's decision to participate in the watershed management strategy was shaped by the individual's previous participation in small purchasing cooperatives (often called gwoupman), their understanding of the general benefits of soil conservation, and their experience with small dam construction on their property. White and Runge $(1994,29)$ conclude that free riding in the watershed management institutions studied was not a dominant strategy, discrediting the assumption made by many policy interventions in Haiti of strong individualism among rural peasants. Even though individualism among rural farmers was not strong to begin with, by offering cash incentives to those who broke from traditional institutions, agencies actually created competitive individualism in many communities.

\section{Ecology and Territoriality}

Projects such as the Péligre Dam were designed to serve populations within distinct political and administrative boundaries, with little or no recognition of more natural ecological units over which such boundaries had been imposed. For example, different communities in the same watershed were affected by development in any one community if the shared watercourse was manipulated. Project Save the Land chose to work in a series of communities stretching along coastal roads that crossed eight watersheds. In the end the US\$15 million project had a negative impact on the people it was meant to serve because it destroyed local institutions and left the population ill-equipped to deal with worsening environmental degradation. People are still leaving the hillsides for Port-au-Prince and the southern coastal cities of Les Cayes and Jacmel.

In 1985 the USAID began to fund a project called Save the Land through several small non-governmental organizations (NGOs) with experience in Haiti. Its goals were to increase local income and reduce environmental degradation, and these goals would be accomplished by encouraging the production of high value crops, reforestation, and soil conservation strategies (Jaffe, forthcoming). Local storage facilities would be improved, livestock health would be monitored, and farmers would be taught how to better market their products. The project included approximately 60,000 families across 80,000 hectares in eight watersheds that flow down the southern exposure of the Massif de la Hotte mountain chain in the southwest arm of Haiti.

Most of the families live in settlements along the coastal road, though the average density of the region was around 5.7 inhabitants for each hectare of arable land. Each farmer cultivated about 1.5 hectares over several different plots of land, some of which was rented. Land resources were unequally distributed among the popula-

Refuge, Vol. 16, No. 3 (August 1997) 
tion, with 10 percent of the population controlling 42 percent of the land.

According to project designers, many farmers had contradictory arrangements with other farmers, simultaneously renting out land to neighbours, renting land from neighbours, contracting labour to neighbours, and contracting labour from neighbours. The project sought to untangle these reciprocal arrangements and replace them with formal markets that could rationally mediate relationships with currency.

Within the region, NGOs targeted only landowners, preferring to work on large properties where they could have a large impact. The local economy was rearranged for the temporary project as local staff demanded larger salaries, nonexistent workers applied for pay, export crops were encouraged over improved subsistence agriculture, and farmers were asked to purchase high yield corn from institutional growers rather than use openpollinated corn from previous seasons. More importantly, the existing tradition of labour-reciprocity was superseded by hierarchical management structures headed by individual community representatives, usually local elites.

Pressure from the USAID for empirical evidence of success drove NGO staff to concentrate directly on measurable, project-based improvements (hedgerows, check dams, and fertilizer use) to the neglect of improvements in the quality of life (democratic participation, physical health or economic sustainability). Although traditional highland farming techniques were less than perfect, a recent study confirmed that the combination of indigenous knowledge with project-based soil conservation and agroforestry results in significantly higher land productivity than either practice alone (White and Jickling 1995). Project Save The Land had few lasting achievements.

Many of the technical innovations brought to combat soil erosion and manage dwindling fuelwood sources were lost when the funding ended. Although traditions of labour reci- procity seemed convoluted at the outset of the project, they had at least allowed disadvantaged families to participate in the local economy and farm at the subsistence level. In contrast, project managers at the top of the administrative hierarchy rarely heard from disadvantaged families. "In the few instances that disapproval was received" writes one observer, "it was in the context of political unrest" (Jaffe, forthcoming). A growing number of impoverished farmers saw their yields decline, and since many could not supplement their income by working in rural areas, they were forced to give up land and migrate to the cities.

Even with migration to the cities, the amount of land available to each farmer in Haiti has decreased substantially over the last three decades. Both the amount of cultivated land per person and per agricultural worker decreased rapidly after 1970 , even though the number of people involved in agriculture also decreased from 73 percent to 65 percent of the total labour force. In 1970, each Haitian farmer had about 0.43 hectares of cultivable land, though today each farmer has less than 0.35 hectares of cultivable land. Overall, the amount of cultivable land has diminished from 0.32 hectares per person to less than 0.20 hectares per person today (World Resources Institute 1994; World Bank 1997). Rapid population growth rates drove up the total number of people requiring land, forest, water and the number of agricultural producers. Environmental degradation drove down the cultivable amount of land and its productive capacity, inducing migration into Haiti's urban centres.

\section{Conclusion: Migration and Collective Grievances}

Mass migrations were not induced by every development project, and not all the people living in Haiti's slums are there only because of environmental degradation in the highlands. Political and economic factors also influenced the decision of individuals to leave rural areas. However, political tensions and economic conditions in many communities were the result of local environmental degradation, rapid population growth, and in-migration from other communities. Population growth itself has been an important source of pressure in Haiti.

In many Haitian communities, development-induced environmental degradation lowered the quality and quantity of forest, land and freshwater resources. This destroyed economic opportunities in rural agriculture and motivated the political demands for land reform and distributive justice, factors which are the most apparent cause of civil violence in Haiti. Severe environmental degradation, either as a direct consequence of large projects like the Péligre Dam or an indirect consequence of certain agrarian development strategies, induced a significant number of people to migrate into Haiti's urban centres. By destabilizing the ecology of rural areas where the population was growing rapidly, many families were unable to continue even subsistence farming.

When migrants brought their grievances to the streets of Port-au-Prince and the neighbouring slum of Cité Soleil they often found people with similar grievances. Here the desperate sense of collective impoverishment was fuelled, and since the mid-1980s mob anger against Haitian elites has regularly threatened to consume the streets with chaos and violence. The surplus of urban labour has grown much more quickly than the formal economy, and since rapid migration into the slums of Port-au-Prince and the district capitals continues, the potential for more violent conflict grows.

\section{Notes}

1. Estimates for the current population of Port-au-Prince range between 1.8-2.5 million, though the largest squatter settlement, Cite Soleil, has never been the subject of a comprehensive census.

2. In 1955, engineers reported that in the area to benefit from irrigation "the average dimension of worked land is 1.2 hectares." However, their report identifies 33,861 parcels of land in 32,000 irrigable hectares, and the average dimension of worked land should probably have been calculated at 1.06 hectares (Zamor 1983, 30). 


\section{References}

Abbott, Elizabeth. 1988. Haiti: The Duvaliers and Their Legacy. New York, NY: McGraw-Hill.

Bryan, Anthony T. 1995. "Haiti: Kick Starting the Economy." Current History (February): 65-70.

Durand, Wilson. 1983. "Enquête sur la Production et la Commercialisation du riz dans la vallée de l'Artibonite." Bulletin Agricole, 19.

Frenette, M. et. al. 1982. "Cas Historique de Sedimentation du Barrage Péligre, Haiti." Canadian Journal of Civil Engineering 9, 206-23.

Jaffe, JoAnn. Forthcoming. "Underdevelopment By Design: How Agricultural Development Programs Increase Poverty and Inequality in Poor Countries-The Case of Haiti." Canadian Journal of Latin American and Caribbean Studies 21, no. 42.

Maingot, Anthony P. 1995. "The Political Rot Within." Current History (February): 5964.

Mintz, Sidney W. 1995. "Can Haiti Change?" Foreign Affairs 74, no. 1, 73-86.

Organization of American States. 1963. Inventory of Information Basic to the Planning of Agricultural Development in Latin America: Haiti. Port-au-Prince: OAS.

Orenstein, Catherine. 1995. "Illegal Transnational Labor: Mexicans in California and Haitians in the Dominican Republic." Journal of International Affairs 48 (Winter): 601-24.

Perez, Federico Cuevas, and Jean René Bona. 1983. "Situation de la Riziculture Haiti." Bulletin Agricole, 9-10.

Schaedel, R.P. 1962. Human Resources of Haiti: An Essay. Port-au-Prince: U.S. Agency for International Development.

White, T. Anderson, and Jon L. Jickling. 1995. "Peasants, Experts, and Land Use in Haiti: Lessons from Indigenous and Project Technology." Journal of Soil and Water Conservation 50 (January-February): 7-14.

White, T. Anderson, and C. Ford Runge. 1994. "Common Property and Collective Action: Lessons from Cooperative Watershed Management in Haiti." Economic Development and Cultural Change 43,1-41.

World Resources Institute. 1994. World Resources 1994-95. Oxford: Oxford University Press.

World Bank. 1997. World Development Indicators. CD-ROM.

Zamor, Guillaume. 1983. "Importance du Cadastre dans la Vallee de l'Artibonite." Bulletin Agricole. $\square$

\section{Tinnalist in the 1997 Themas 8 Hmaniedci. Priate}

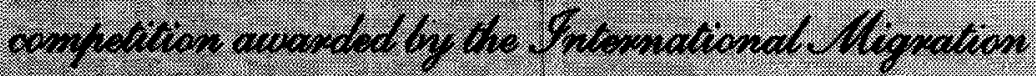
Soctian of tha Atmonican fociological Stesciartion

\section{Paths To EQuity}

\section{Culturel, Linguistic, and Recial Diversity} in Canadian Earty Childhood Education By

\section{Juith XC Beriben, Marie Lowise Lffebure, Gyda Chud, and Rikn Longe \\ Toronto: Tork tages Press

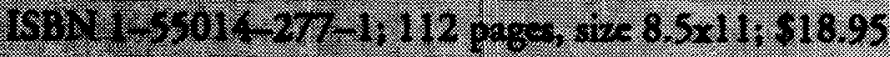

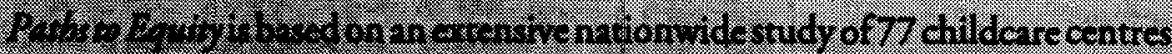
in Monined, Toronto, and Vancouver on the calhural, linguistic, and racial divertioy in CondiennEaty Childhood Education (ECE). The report presents the fesulfs this study on tow the ECE systen is responding to the increasing diverity of contemporeny Camadian society.

A fully onc third of teachers intervieved in this study terponded, at the time of graduarion froin ECE programs, did not foel that they were well prepared co workeffectivety with ebild ren and parehts from diverse backgrounds. In this ground breal ing gudf, the authars hive dd dresed teachers' views on diversity in the duenton programs parents diffeculates in collaborating within the

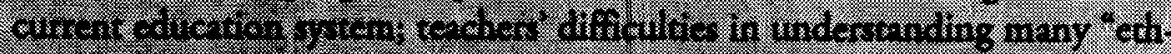
nic' parents derire of many perents for berter communication with staff, preferbbly in thil omn longunges, and for more information abour their individual childen, and thenow for effective input; and the evidence of some conthiting problen with racian, irrespoctive of the good intentions of centre wint

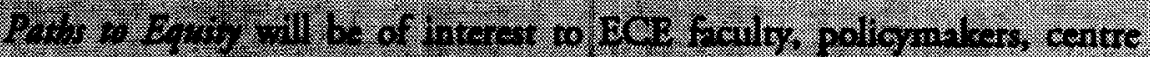

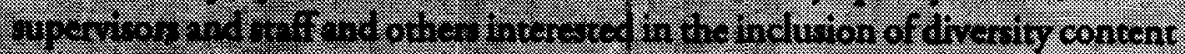
is profevionat atication prograns.

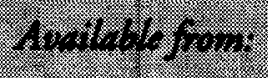

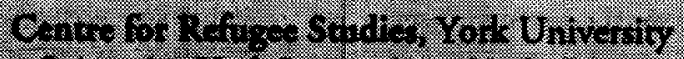

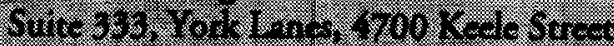

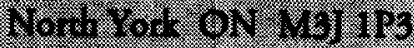

18-1416) $736-5837$

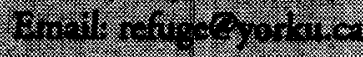

(C) Philip Howard, 1997. This open-access work is licensed under a Creative Commons Attribution-NonCommercial 4.0 International License, which permits use, reproduction and distribution in any medium for non-commercial purposes, provided the original author(s) are credited and the original publication in Refuge: Canada's Journal on Refugees is cited. 